\title{
A Critical Pragmatic Study of Racism as Conceptualized in the Glorious Quran
}

\author{
Wafaa Sahib Mehdi Muhammed \\ University of Baghdad/College of Languages/Department of English \\ Wafaa_1972@yahoo.com
}

DOI: https://doi.org/10.36231/coedw/vol31no2.11

Received 2020/2/10

Accepted 2020/3/10

\begin{abstract}
Racism changes its meaning, shape, purpose or function according to various factors such as time, place, motives, and backgrounds; among others. It seems, however, to have deep roots back in the history of mankind. Such a concept stems from a perceived difference with the other. It is fed by the feeling of being hierarchically superior in opposition to another party that is depicted as inferior. Since ancient times, racism is disguised in different forms and manifests itself on various levels. It is a truism that this ideology can be best presented via language.

Due to its negative implication, racism lends itself to a critical kind of research. As such, this paper is a critical pragmatic investigation for this phenomenon as conceptualized in the Glorious Quran. Critical pragmatics focuses on how the pragmatic theories scrutinize the reflection of a negative issue in language where aspects of power or ideology are highlighted. These theories, in turn, provide the pragmatic strategies that underpin the illegitimate issue under investigation.

This paper sets for itself the task of answering these questions: How is racism manifested in the Glorious Quran by the unbelievers? What are the pragmatic theories that are utilized to impart this notion? It aims at finding out the manifestations of racist ideology in the Glorious Quran and discovering the pragmatic theories utilized to convey racism. It is hypothesized that racism is realized explicitly and implicitly. Basic pragmatic theories are utilized to convey it such as referencing or speech acts. A number of racist utterances in the Glorious Quran are fetched to be under scrutiny. The analysis verifies the set hypotheses. It is hopeful that this study is beneficial to those interested in linguistics and religious studies.
\end{abstract}

Key words: Critical Pragmatics, Quraanic Studies, Racism 


\title{
دراسة تداولية نقدية للعنصرية كما يصور ها القران الكريم وفاء مهذي صاحب \\ قسم اللغة الانكليزية / جامعة بغداد
}

\begin{abstract}
الملخص
يتغير معنى العنصرية وشكلها و غرضها ووظيفتها تبعاً لعو امل عدة مثل الزمان و المكان المان و الدافعية وما الى ذللك، لكن على مايبدو

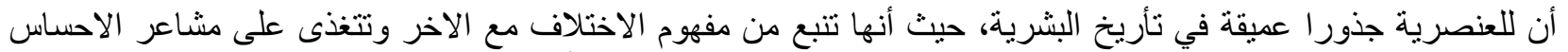

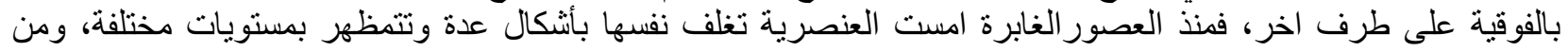
الحقائق الجلية انه يمكن عرض هذا المفهوم عن طريق الاستعمال اللغوي.

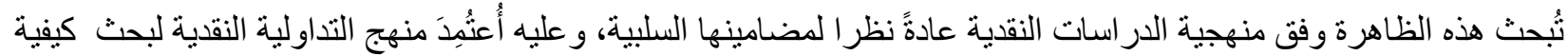
عرضها في القرآن الكريم. يركز مبدأ التداولية النقدية على كيفية انعكاس قضايا سلبية في اللغة باستعمال النظريات النية التداولية حين

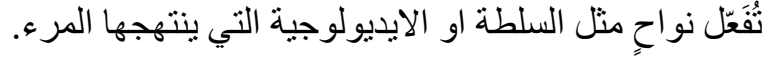

تضع هذه الدراسة لنفسها مهمة الاجابة عن الاسئلة الاتية: كيف تُعرض العنصرية في القرآن الكريح؟ ماهي النظريات التداولية

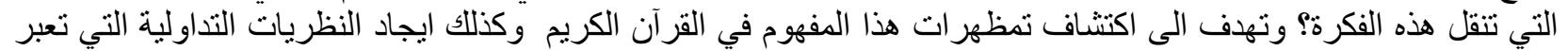

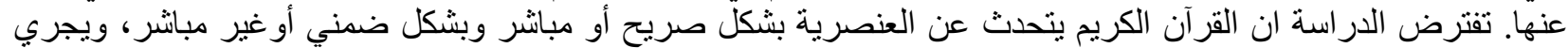

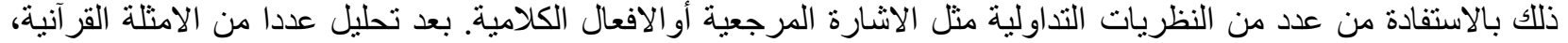

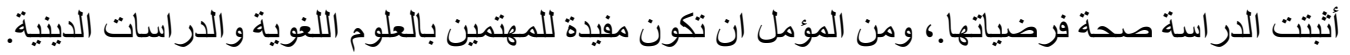

الكلمات المفتاحية: التداولية النقدية، دراسات عن القر آن الكريم، العنصرية
\end{abstract}

\section{Introduction}

To claim that racism is not confined to a specific place or time seems to be a fact. Saying that it is found in different forms and levels in various times and places of this universe is another undeniable fact. Racism can be motivated by historical, cultural, economic or religious reasons. Due to their racist ideologies, unbelievers rejected to listen to the calls of believers or messengers of Almighty Allah when asked to do so. One can find some direct and indirect instances of racism in the Glorious Quran. These are motivated by bigotry to religion, adherence to ancestral affiliation, discrimination to gender and the tendency to one's status.

Racism has been defined differently, but all definitions share the idea that it is the negative feeling against others due to a perceived difference in religion, race, ethnicity and the like. This kind of feeling is usually accompanied by a racist practice that is characterized by opposition, hatred, hostility or inconvenience. Such critical aspects need to be approached in terms of the critical theory to social interactions. As one kind of the critical studies on discourse, similar to critical discourse analysis and critical stylistics, critical pragmatics is the discipline that is introduced in this research paper to fulfill this kind of task and be the tool of analysis. 


\section{Definitions of Racism}

It is not easy to agree upon a definite and distinct definition for racism. Essed (1991, p. 39) views racism as an ideological construction where a relationship of power is sustained in a process of domination exercised by one person or group against another. For Guillaumin (1995, p. 30), "racism is a symbolic system operating inside the system of power relations of a particular type of society". It is a problematic term that is used loosely and unreflectively to describe all the negative hostile feelings towards others and the actions emerging from such an attitude (Fredrickson, 2002, p. 1). It is motivated by the concept of difference that is proposed and sustained in a hierarchy of order which is almost claimed to be natural (ibid., p. 6). Generally speaking, this negative feeling is inspired by a difference in terms of race, religion, ethnicity, sex, nationality, status and the like.

Most scholars agree that it comprises a problematic complex set of practices, beliefs and relations (Leonardo and Grubb, 2014, p. 143). Such negative practices are represented by disrespect, opposition, hatred, violence, injustice, preventing others' rights, discrimination, inequality, harassment and so on. It is fed by prejudice and pejorative beliefs. Grigga and Manderson (2015, p. 169) remark that "theories of racism vary from those understanding racism as inevitable, to those attributing racism to personality characteristics, to those proposing racism to be a product of societal norms and discourse" (ibid.). As far as the Glorious Quran is concerned, two attitudes can be detected concerning this notion: the racist and the anti-racist. This example proves the fact that racism did exist in human beings' thinking since ancient times of history. It anticipates that it is established and it will always remain in those who advocate such an ideology for their benefit and interests. The following verse exemplifies the anti-racist attitude:

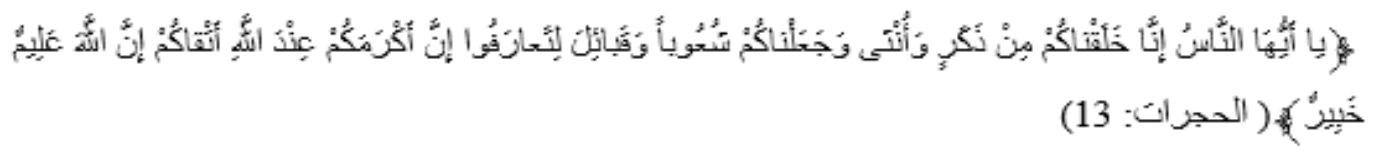

O mankind! We created you from a single [pair] of a male and a female, and made you into nations and tribes, that ye may know each other [not that ye may despise [each other]. Verily the most honoured of you in the sight of Allah is [he who is] the most righteous of you. And Allah has full knowledge and is well acquainted [with all things] (Ali, 1987, p. 262).

It is worthy to remember that the first incidence of racism occurred when the Satan revealed his rigorism and obstinacy against Allah's order to show submission and reverence to Adam. It is motivated by a status- coded perspective where the devil argues that he is better than Adam as he is created from fire which, in his own view, is better than clay. This point of view is completely wrong. The following verse shows what the devil said when asked to prostrate:

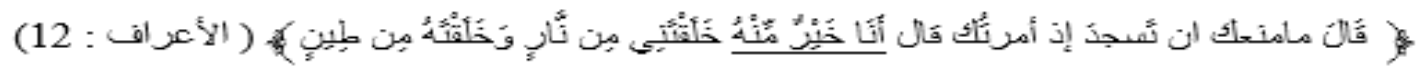

[Allah] said: "What prevented thee from prostrating when I commanded thee?" He said: "I am better than he: Thou didst create me from fire, and him from clay" (Ali, 1987, p. 68) 
To sum, the Glorious Quran portrays the notion of racism directly (explicitly) and indirectly (implicitly). The first is articulated by a specific speaker (or speakers) who is usually an unbeliever whereas the second is told or narrated by Almighty Allah about those unbelievers. The first is put under scrutiny as it has an actual linguistic realization whereas the second is out of the realm of this paper because it is just narrated by Almighty Allah. The instances that are looked for in the Glorious Quran are a sort of a response given by the unbelievers when they are invited to believe in Almighty Allah and they refuse to do so due to the racist tendency. If racism is conveyed directly, it is usually found after the verb of saying ( قالو ا/قال ) and it is told by unbelievers who oppose the messengers of Almighty Allah or the believers. Racism falls into one of the kinds that are to be presented in the following section. These are considered as the criteria for judging that a certain utterance bears a racist tendency.

\subsection{Motivations for Racism}

Garner (2010, p. 18) coins the term racisms to refer to the fact that racism cannot be discussed in the abstract. Reference to particular times, places and conditions needs to be accounted for. Racism, thus, is never understood without a specific context. It is fetched in this study throughout the verses of the Glorious Quran. Racism is ignited by a number of motivations, as far as the Glorious Quran is concerned. Some basic ones are set below. Each motive denotes one kind of racism and justifies the power aspect behind adhering to this ideology.

\subsubsection{Religious Bigotry}

The relationship between religion and racism is vital. All world religions are supposed to have a common base of peacefulness and brotherly love. Historical events, however, show that religion has been behind many kinds of catastrophes and atrocities directed towards people because they are from different religions. The Crusades or the Holocaust are some examples (Duriez and Hutsebaut, 2000, p. 87). Due to the deviations that happened in the divine instructions of Almighty Allah, some people imagine that their religious belief is better than others. The Jews maintain that they are the chosen people of Allah rather than the Christians who feel that their religion is the preferred one. When عانشور (1986, p. 3) presents his eighteen different definitions interpreting the meanings of racism, he states that the portraying of the Jewish religion as the best one is one form of racism. As a matter of fact, all messages from heaven convey the same concept: people are created to worship Almighty Allah and believe in the call of His Prophets and that Islam is His religion, as this verse emphasizes:

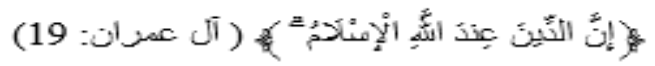

The Religion before Allah is Islam [submission to His Will] (Ali: 1987, p.22)

\subsubsection{Ancestral Affiliation}

This kind of racism is motivated by the strong familial affiliation on one hand and the rejection to change, on the other. Those who are invited or ordered to follow the righteous religion of Almighty Allah and abandon worshiping the statues that their parents or grandparents honoured show resistance. They claim that they are on the right path. One holly verse says: 


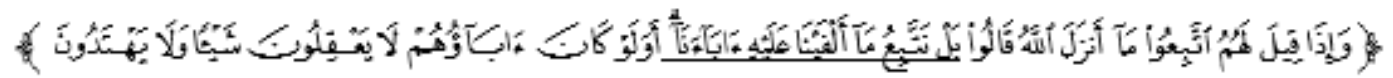

(البقرة: 170)

When it is said to them: "Follow what Allah hath revealed:" They say: "Nay! we shall follow the ways of our fathers." What! even though their fathers Were void of wisdom and guidance? (Ali, 1987, p. 11).

Allah has created people into many different nations and tribes so that they may know each other and live harmoniously together. It is good when one is committed to his tribe or family. However, a total blind following is not always recommended. Prophets invite people to the righteous religion of Allah clarifying that the parents' way is sometimes wrong. People must listen and think and never stick blindly to their previous habits and traditions. Human beings have been endowed minds and the bliss of thinking and they have to abide by that.

\subsubsection{Status- Coded Racism}

Racism is invoked by a higher status perspective in terms of wealth, education, technological developments, among others. This state of affairs has long been noticed since old times. It yields a hierarchical ordering of the groups in the society (Trudgill, 2000, p. 25). Higher class groups enjoy a higher status than lower class ones (ibid., p. 74). Thus, in some societies, those of higher status are more liable to practise racism against others if they are richer, more educated or hold higher positions. Europeans, for instance, regard their dominance over other parts of the globe as a consequence of the cultural and technological advancements which led them to gain higher status in terms of wealth, education and so on (Fredrickson, 2002, p. 61).

Here are two examples that explicate the kind of wealth racism. The first one bears an implicit reference to status- coded racism, which is based on wealth. In Al-Masad Sura, Abu Lahab thinks that his wealth and money will save or protect him from the fire of punishment (قارة) 1995, p. 61). The second example is an explicit representation of this kind of racism. The unbeliever person in The Cave Sura had two gardens and a lot of money. He told the believer person that he is richer and more powerful. The two examples are:

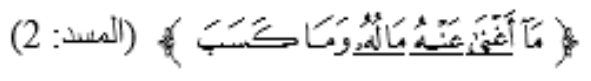

No profit to him from all his wealth, and all his gains (Ali, 1987, p. 324)

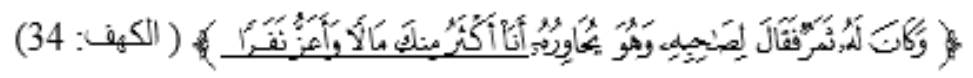

[Abundant] was the produce this man had : he said to his companion, in the course of a mutual argument: "more wealth have I than you, and more honour and power in [my following of] men." (Ali, 1987, p. 140). 
The first verse says that wealth is not the criterion in Allah's judgments. The second illustrates how wealth is a weak base to rely on. This elucidates the idea that racism is a negative issue which should be exposed to the open so as to be condemned, opposed and rejected.

\subsubsection{Gender- Based Distinction}

To discriminate is to make a difference in treatment on a categorical basis (Graumann and Wintermantel, 1989, p. 183). Wodak (2009, p. 315) stipulates that gender- differentiation is one form of discrimination. In this regard, women are marginalized and segregated against. Accordingly, one form of racism is realized by gender differences whereby one dominant group (usually males) discriminates against the other oppressed sex (usually women). Sexism is a product of the dominant patriarchal ideologies where males are superior to females in the social hierarchy (Al-Hindawi and Mohammed, 2018, p.166).

Work in sexism alludes to the issue of sex and gender. It is suggested that gender refers to "the social process of dividing up people and social practices along the lines of sexed identities" in the sense that the two are distinct and opposed categories with a polar hierarchy (Beasley, 2005, p. 12). Sex refers to the "biological or anatomical differences between men and women"; gender, on the other hand, " concerns the psychological, social and cultural differences between males and females" (Wodak and Benke, 2007, p. 89).

To be a man or woman is a matter of social reality which has its effects on the different opportunities, rights and constraints gained in society. Thus, gender is a social term while sex is a biological one. Some research scholars, however, use the two terms interchangeably (ibid.). It is worthy to mention that Scruton $(2007$, p. 646) maintains that "either sex may be the object of sexist attitudes". Women, however, have always been the target victims in almost all societies since the ancient times (ibid.).

The implicit reference to the preference of men over women is narrated in the following verse. Before Islam, if someone had been told that his wife gave birth to a female child, his face would have been filled with sadness and grief. The black colour in this verse means anguish and sorrow:

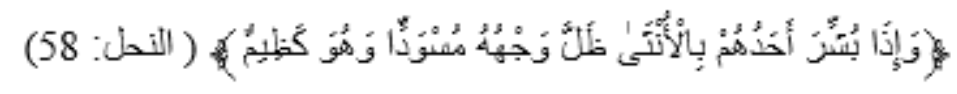

When news is brought to one of them, of [the birth of] a female [child], his face darkens, and he is filled with inward grief (Ali, 1987:127).

\section{Critical Studies}

Since racism is a negative issue, it can easily be covered under the umbrella of the critical paradigm led by the critical theory. The moral and ethical improvement of society is a representative part of the critical theory owing to the fact that its fundamental promise is to rationalize and explain how to help improve society (Leist, 2008, p. 1). This improvement may imply setting the right and establishing justice and preventing wrongs to continue. The critical theory is a school of thought that flourished in Frankfurt Germany since 1929/1930 to the present time (Bohman, 2016, p. 1). When capitalized, Critical Theory refers only to the Frankfurt School 
whereas any philosophical approach that enjoys close practical aims is termed critical theory such as feminism, post-colonialism, critical race theory and so on (ibid.).

According to Geuss (1981, p. 3), the Frankfurt School designates three distinctive theses for critical theories: they have a special standing as a guide to human action; they have a cognitive content (i.e. as they are forms of knowledge); and they are reflective. As a philosophical enterprise, its main concern is the reflective assessment and critique of society and culture fed by knowledge from humanities and social sciences (ibid. p. 2).

One version of the critical theory is the critical theory of society that arguably arose from the work of Marx whose very heart is its criticism of ideology (ibid., p. 3). Its constitutional claim is how things came to be the way they are now as well as in the future (How, 2003, p. 3). When a critical analysis is incorporated into the linguistic aspects of discourse, we have what is called Critical Linguistics. Crystal (2003, p. 117) defines it as the branch of linguistics that seeks to uncover ideological processes and hidden relations of power in any text, spoken or written.

One prominent approach to critical studies is critical discourse analysis. It is the discipline that investigates "the relationship between discourse events and sociopolitical and cultural factors" and how discourses ideologically influence and are influenced by power relations in societies (ibid., p. 118). Another approach is that of critical stylistics which introduces a set of tools that explain why a specific text is seen as powerful (Jeffries, 2010, p. 2). This study launches the critical pragmatic approach (See section 4 on critical pragmatics).

A critical study needs to introduce some basic concepts. Wodak (2007, p. 209) avers that stance, critique and ideology and even history are indispensable items in critical works. The key terms important to this study are presented as follows:

\subsection{Stance}

Wodak (1989, p. xvi) sustains that researchers and analysts are forced to take sides. A crucial and inherent theme in the critical work is that an explicit stance should be undertaken by the analyst, as van Dijk (2001, p. 352) holds. Originally, stance is a "public act by a social actor, achieved dialogically through overt communicative means, of simultaneously evaluating objects, positioning subjects (self and others), and aligning with other subjects, with respect to any salient dimension of the sociocultural field" (DuBois, 2007, p.163). By doing this, analysts reflect their value system and their community (Bloor and Bloor, 2007, p. 49). In a similar vein, Johnstone (2008, p. 137) claims that stance (or the better term: stancetaking) involves a comparison against a norm. Stancetaking is a form of social action that involves the expression of personal attitudes, evaluations or beliefs concerning events (Arrese et al., 2017, p. 1). In approaching any discourse, critical analysts need to recognize the stance they adhere to in advance. This study highlights dismantling the racist ideology. Thus, it advocates the ethical anti-racist stance that is measured in alignments with the Prophets' guidance or Almighty Allah's instructions.

\subsection{Critique}

In critical studies, the interpretation of the word critical is ambiguous. By this word, theorists refer to the idea of critique and not to mere criticism where the latter involves imposing norms over facts (How, 2003, p. 4). A critic, in this sense, objects to certain state of affirms according to his own reasons which give privilege to the critic's position as valid without meeting critical criteria (ibid.). Critique, on the other hand, presupposes the criteria that give justifications 
to the situation (ibid.). Accordingly, critique looks for reality to pull it where it should be and what it would become. As such, critique is more than criticism as it must be grounded on historical circumstances and it should be immanent with its potentiality to generate a better view of life (ibid., p. 9).

When Fairclough (1995, p. 28) posits descriptive studies against critical ones, he defines critique as "essentially making visible interconnectedness of things" (ibid., p. 36). He associates the term critique to critical. In this paper, doing critique is based on the divine criteria that prophets and messengers of Almighty Allah are argued with. Critique in this work means pointing at the racist instances and explaining them to the public. Critical pragmaticians need to undertake such a responsibility.

\subsection{Ideology}

Determined by social or historical factors, any piece of discourse is created as a communicative action geared towards certain goals; a close relation joins the actual linguistic realization of texts and the social settings in which they are originated (Schjerve, 1989, p.58). One may examine this social setting and the ideological forces correlated to its linguistic realization critically (ibid.). This requires a wide knowledge in the historical, social, religious and political contexts. According to Verschueren (1999a, p. 238), the constellation of commonsensical, fundamental (and usually normative) ideas and beliefs that are related to certain aspect(s) of social reality is defined as ideology. It refers to "how we think, speak and argue" (van Dijk, 2004, p. 56). Bloor and Bloor (2007, p. 10) gloss the term by defining it as the "set of beliefs and attitudes shared by members of a particular social group". Hill (2008, p. 34) pertains that ideology as a way of thinking or a perspective saturated with political and economic interests in the first place. Van Dijk's (1998) ideological theory, however, sums up an understanding of this notion putting its three cores as follows:

a. Cognitively, ideology constitutes ideas in people's minds. This is the concern of cognitive psychologists (ibid., p. 15).

b. Societally, ideology involves the membership of a group and value judgment; these are generally investigated by sociologists and social scholars (ibid. p.135).

c. Linguistically, ideology is learnt, acquired or changed through written or spoken discourse since it is not an innate knowledge (ibid., p. 191).

In this regard, this research paper adopts the definition of the notion of ideology as a cognitively determined concept that is manifested via language use.

\section{Critical Pragmatics}

Pragmatics is conceived as a loaded discipline as Bolinger (1980) observes in his book entitled: Language: The Loaded Discipline, hinting at hidden aspects in language use (Verschueren, 1999b, p. 896). On the occasion of the $70^{\text {th }}$ birthday of Professor Jacob Mey and his retirement at the University of Odense in 1996, a conference was held where authors were invited to present papers on Pragmatics: The Loaded Discipline to highlight an innovative theme in the conference whereby contributors have to take "a critical approach to the subject of pragmatics" with a view on its current state and its upcoming future. The occasion of the conference can be said to designate the early birth of critical pragmatics. It encouraged the 
eclecticism between criticality, pragmatics and language use where emphasis is to be on social power to point out language abuse (ibid.).

The amalgamation of criticality and pragmatics has opened a new stream of linguistic research that would widen the horizons of pragmatic potentials. In the (2001) version of his book entitled Pragmatics: An Introduction, Mey (2001, p.316) introduces the term critical pragmatics in a separate section stating that he has the works and articles of van Dijk (published since 1990) and others in mind. The emphasis is on the relationship between language use and social power (Mey, 2001, p. 315). Melefa and Emeka (2014, p. 157) argue that this discipline is not interested in different language use merely as a matter of linguistic variation, to be described and classified in purely theoretical terms, or to be analysed with the aid of sociological variables denoting class, race or other parameters. It focuses on the ways that help us distinguish or recognize social discrimination to oppose it.

Korta and Perry (2011, p. 3) explain why critical pragmatics provides a coherent overview on how parts of language study fit together within the broader picture of human thought and action. In other words, the essential objective is to portray a picture of how parts of language are used to materialize human thoughts and actions because it critically tries to probe into how human beings use language so as to shape and influence the realities of the community to which they belong. This being said, the assumption that people may show power over others by their use of language becomes plausible. Accordingly, critical pragmatics is, operationally, defined as an analytical methodology that looks for how the pragmatic paradigm is utilized to impart negative issues where aspects of power or ideology are illustrated via language abuse rather than language use.

\subsection{Relevant Pragmatic Issues}

This section looks for the pragmatic issues that have been utilized by the unbelievers or those people who adhere to the racist ideology when they are called on to believe in Almighty Allah and His religion. Four main theoretical frameworks underpin the current work: speech act theory (Searle, 1969, 1976 and 1979), the theory of politeness (Brown and Levinson 1987), strategic maneuvering (Eemeren and Houtlosser, 2000 and 2009) and reference (Korta and Perry, 2011).

\subsubsection{Speech Acts $(\mathrm{SA} / \mathrm{s})$}

The engagement in any communicative encounter entails the use of various SAs. A racist person may resort to a certain SA to convey his attitude and achieve his goals. To talk of goals, purposes, plans, illocutions or meanings is to be indulged in a functional orientation in language use (Leech, 1983, p. 48). The functional theory shows how language operates within human society as a form of communication. The essence of Austin's (1962, p. 101) theory is that saying is doing. Searle (1969, p. 54) sets four felicity conditions for the successful execution of an illocution: propositional, preparatory, sincerity and essential conditions. The classification of basic kinds of meaningful utterances is based on the notion of illocutionary point (Searle, 1979, p. $3)$.

A classification of five macro categories of SAs has been introduced (Searle, 1976, p. 1720) where each one of them constitutes a host of other sub- acts distinguished from each other by their own felicity conditions. These are: commissives (the speaker is committed to doing something as in promising), declaratives or declarations (the speaker's utterance causes an 
external change like declaring a war), directives (the speaker gets people to do something such as requesting), expressives (the speaker expresses his feelings and attitudes like criticizing) and representatives/assertives (the speaker informs others about the truth as in affirming) (ibid.).

One needs to notice that an utterance is not racist per se unless we identify other factors to classify it as such (Graumann and Wintermantel, 1989, p. 205; Wodak, 1989, p. xv). Skinner (2008, p. 647) expounds that SAs need to be understood in relation to the circumstances in which they are issued. The analysis in this research utilizes the macro acts of Searle (1976) with their micro sub-acts. Thus, the macro act of directive speech acts has a micro sub-act like requests or commands.

\subsubsection{Politeness}

Brown and Levinson's theory (1987) comprises the nature of politeness, its functions in interaction and its strategies. They assume that most speech acts like requests, complains, offers or complaints inherently threaten either the hearer's or the speaker's face-wants. Politeness is involved to redress those face-threatening acts which are directed toward the negative or positive face of interlocutors. Four types of politeness strategies are outlined in their model that sum up human politeness of behavior. These are: bald on record, positive politeness, negative politeness, and off-record-indirect strategy.

Brown and Levinson $(1978,1987)$ aver that three sociological factors have a significant role in selecting the strategies in performing a face-threatening act: social distance between parties, power relations, and the degree of imposition of the speech act. Their positive politeness comprises three major super strategies which, in turn, are realized by some sub- strategies (1987, p. 107). These are claiming common grounds with the hearer, conveying that speaker and hearer are cooperatives and fulfilling wants of hearer. For example, a positive politeness strategy can be realized by using an in-group identity marker (ibid.).

\subsubsection{Strategic Maneuvering (SM)}

The concept of strategic maneuvering has evolved within the pragma-dialectic model of argumentation introduced by Eemeren and colleagues (See Eemeren and Houtlosser, 2000, 2009) to deal with argumentation. This model is known as the pragma-dialectic model of 'critical discussion' that provides an overview of the argumentative moves that are essential to the completion of each of the discussion stages. A difference of opinion on the merits in each particular stage is supposed to be resolved (Eemeren, 2009, p. 40).

According to Eemeren (2009), the analysis of strategic maneuvering divides the persuasive dimension into three basic inseparable aspects: topical potential, audience demand and presentational devices (Eemeren, 2009, p. 90). The first dimension of topical potential involves selecting materials from those available in terms of what is believed to be the best to serve the advantages of a speaker (Tindale, 2009, p. 43). Arguers choose topics from a list of topics available at their disposal that best advance their interests (ibid., p. 4). As far as the second aspect is concerned, the positive strategies of Brown and Levinson (1978) can be utilized to show audience- demand manifestations. The third aspect relates to rhetoric which can best be defined as "the theoretical study of the various kinds of persuasion techniques that can be effective in argumentative practice" (Eemeren and Houtlosser, 2006, p. 38) since rhetoric is the science of persuasion. In other words, 'strategic maneuvering' manifests itself in argumentation in the various adaptations and choices that are taken from the topical potential available at a given stage 
in the discourse, in audience-oriented framings of the argumentative moves and in the purposive use of presentational devices.

\subsubsection{Reference}

In referencing, meaning is relative to a specific situation or context (Crystal, 2003, p. 231). Reference occurs when a speaker intends to impart a piece of information about a particular object with a certain property or a certain relation, as contemporary philosophy claims (Korta and Perry, 2011, p. 12). In this regard, meaning is associated with reference which is the relations that hold between linguistic expressions and what they stand for in the world (Archer et al., 2012, p. 25).

This study adopts Korta and Perry's (2011, p. 12) classification of referencing. It houses deixis, proper names, definite descriptions and demonstratives. Within the pragmatic framework, referring is the central topic that has its deep roots in the philosophy of language and in the semantic realm (Korta and Perry, 2013, p. 163). Deixis is "the study of deictic or indexical expressions in language", as Levinson (2007, p. 100) has previously specified. These are pragmatically determined (ibid., p. 97).

Deixis falls into distinct semantic fields. One representative category of deixis is presented by Levinson (1983, p. 54): personal (you, me), spatial (here, there), temporal (now, then) and social pronouns (Mr., his highness) (cf. Lyons, 1995, p. 302). To construct an out-group relevance, the third person plural pronouns they and them are used as exclusive pronouns. By contrast, the first person plural pronouns we and $u s$ are inclusive and constitute an in-group reference (Hart, 2010, p. 60). In conveying racism, the contrast of we/us vs. they/them is utilized to show the positive aspects of self and the negative aspects of the others.

\section{The Analytical Framework}

According to the previous discussion, an analytical framework can be engineered to be the basic apparatus for the analysis. Figure (1) explains that racism in the context of the Quran has two mentions: indirect and direct. These are the macro types of racism. It is stipulated that racism, in the Glorious Quran, is fed by religious, ancestral, status-coded and gender- differentiated motivations. These are considered as the types of racism in a micro level. It is important to mention that only the direct instances of racism are put under investigation. These are manifested pragmatically via speech acts, politeness strategies, strategic maneuvering and reference. These pragmatic theories are built upon the work of Searle (1976), Brown and Levinson (1987), Eemeren (2009) and Korta and Perry (2011), respectively. Thus, the model of analysis is an eclectic one which has elaborated in terms of the review of literature in this study and in terms of a previous work of the researcher (Al-Hindawi and Mohammed, 2018).

Since a critical issue is discussed, the ethical stance of anti-racism is advocated. The oval shape reflects the idea that critique, (symbolized as CR), is noticed throughout the whole process of analysis. This is schematized in Figure (1) below as follows: 


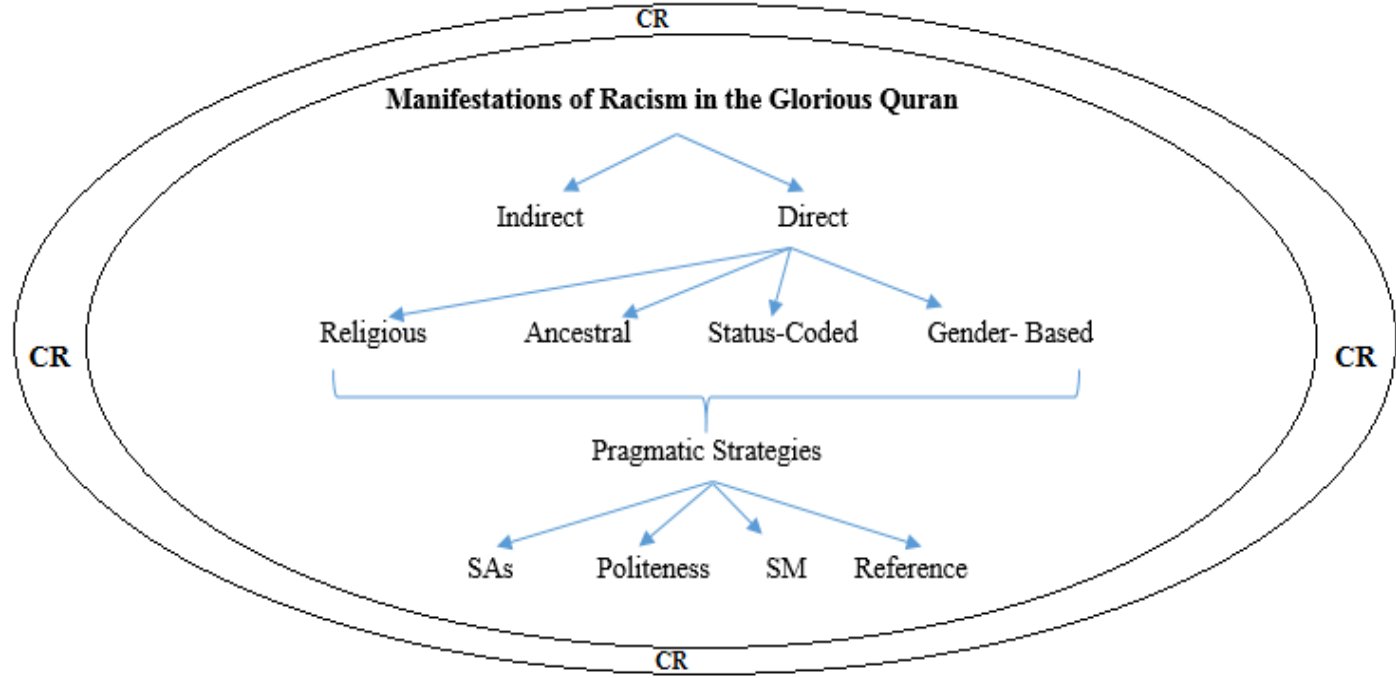

Figure (1): The Analytical Framework of Racism as Conceptualized in the Glorious Quran

\section{Data and Analysis}

\subsection{Data Description and Collection}

This study looks for some verses from the Glorious Quran that bear a racist ideology. The kind of racism is specified first then the utterances are scrutinized to decide what pragmatic strategy has been used by those unbelievers to impart their argumentative mode of racism. Due to space restrictions, some verses have been selected for the analysis. The verses are analysed in terms of the model developed in the previous discussion and represented by Figure (1). Further details in the strategies are not outlined as they are to be unfold throughout the analysis itself. It is worthy to mention that these instances are responses of the unbelievers or Jews or Christians which were given in the arguments they hold with the followers of Allah or believers in Him and in His messengers.

\subsection{Data Analysis}

\section{Example (1):}

The following verse talks about the Jews and Christians who claim their closeness to Almighty Allah. They show their religious racism by claiming that Allah is not going to punish them as they are His people and the ones whom He loves. They argue that they belong to His messengers whom they claim to be His sons (رضا, n.d. p. 316). They believe that they are the chosen people of Allah and their religion is the best (المرعشليا, 2004, p.244). Thus, they show a religious kind of racism. It is expressed via the pragmatic manifestation of the representative SA of affirming (See Searle, 1969, p. 66) for the felicity conditions of this SA). It is exemplified as well by utilizing the referencing strategy of the personal pronoun (نحن ). Allah Almighty says: 


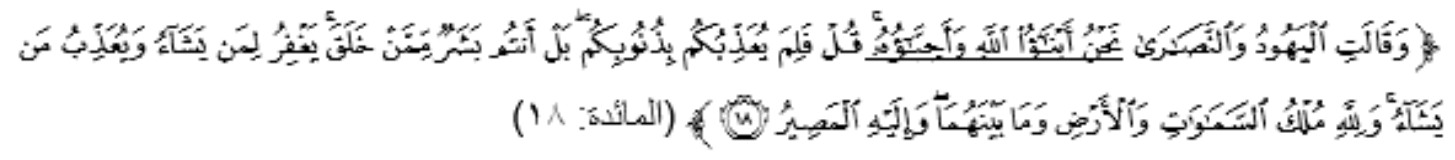

(Both) the Jews and the Christians say: "We are the sons of Allah, and His beloved." Say: "Why then doth He punish you for your sins? Nay, ye are but men of the men He hath created: He forgiveth whom He pleaseth. And He punisheth whom He pleaseth: And to Allah belongeth the dominion of the heavens and the earth, and all that is between: And unto Him is the final goal (of all)." (Ali, 1987, p. 48).

\section{Example (2):}

The following verse elucidates the ancestral and parental affiliation. The people of Salih (peace be on him) expected that Salih will rise them due to his wisdom, intelligence, maturity, and dignified personality. However, Salih began to teach his people that they are obligated to exclusively worship Allah and get rid of the deities they used to believe in. They reject that due to a simple reason which was that their ancestors had worshipped those deities. The rationale they offered shows their racist ideology of following their parents and tribes. They are proved to be wrong and without thinking of the validity of the argument they had with Salih (الطبري, 270 H., p. 228). Allah Almighty says in His glorious book:

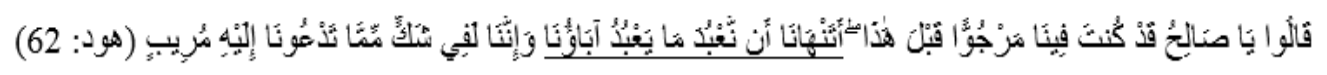

They said: "O Salih! thou hast been of us! a centre of our hopes hitherto! dost thou [now] forbid us the worship of what our fathers worshipped? But we are really in suspicious [disquieting] doubt as to that to which thou invitest us."(Ali, 1987, p. 103).

In this verse, the unbelievers argue using a positive politeness strategy which is using an in-group identity marker (فينا) In such a case, they employ the audience demand aspect of SM by claiming a common ground with speaker. Calling Prophet Salih by his own name shows recognition and consideration. This assumes a positive politeness strategy which is attending to their hearer's interest that is of calling him by his own name. They utilize the SA of blaming to express their racist ideology of ancestral affiliation. The felicity conditions of the expressive SA of blaming are proposed by the researcher as follows:

1. Propositional content conditions: a previous act has been done by hearer.

2. Preparatory conditions: speaker believes that this previous act is bad.

3. Sincerity conditions: speaker is dissatisfied with the present state of affairs resulted by that act.

4. Essential conditions: speaker sets hearer responsible for an act that is blameworthy.

Another SA is used; it is that of questioning (See Searle, 1969, p. 66) for the felicity conditions of this SA). They put their objection to what Salih is saying in the form of a question to minimize the illocutionary force of their argument and to lessen the degree of imposition.

\section{Example (3):}


The following verse shows how the racist ideology advocated by a status- coded perspective is conveyed. It is here ignited by the wealth aspect of relevance. The holly verse says:

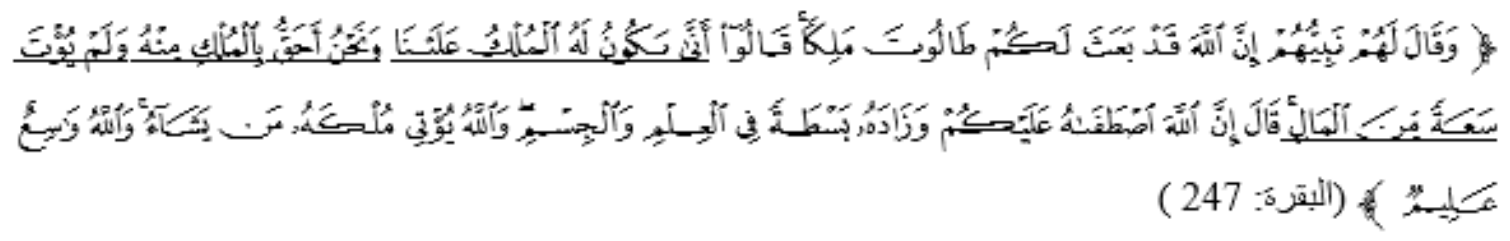

Their Prophet said to them: "Allah hath appointed Talut as king over you." They said: "How can he exercise authority over us when we are better fitted than he to exercise authority, and he is not even gifted, with wealth in abundance?" He said: "Allah hath Chosen him above you, and hath gifted him abundantly with knowledge and bodily prowess: Allah Granteth His authority to whom He pleaseth. Allah careth for all, and He knoweth all things." (Ali, 1987, p. 18).

Here, the unbelievers think that they are supposed to hold authority as they are richer and more adequate for such a powerful status. Two utterances are the response of the unbelievers. They first use the SA of questioning. Then, they utilize the SA of affirming. The questioning act shows their rejection of appointing Talut as their king. He was not rich because his job was to water people (الطبري, 270-H, p. 40). Thus, he is not qualified to be their king. Allah gave him knowledge and strength which are more important than money. He had been chosen by Allah to be the leader. Reference has been manipulated as well by the use of (نحن) as opposing him (منه), i.e. Talut. In this regard, they argue that we are better than him as we have money which is their criterion of leading others.

\section{Conclusions}

The study has come up with the following remarks:

1. Racism is the ideology that seems to have been naturally prevalent in the minds of human beings since old times, as the Glorious Quran reports that implicitly and explicitly. When implicit, it is narrated or reported by Almighty Allah while it is explicit when uttered on the tongues of the unbelievers. This verifies the first hypothesis of the study.

2. In the Glorious Quran, racism is motivated by a difference in religion, ancestry, status and sex.

3. Racist unbelievers reflect their ideology via the pragmatic phenomena of speech acts, politeness, strategic maneuvering and referencing. Thus, the second hypothesis is partially verified because other pragmatic aspects (namely politeness, strategic maneuvering) appear to impart racism in the context under scrutiny.

4. The kind which is based on the difference in sex is not noticed explicitly due to the fact that no direct argument is reported with a woman in all the verses of the Quran. 


\section{References}

Al-Hindawi, F. H., \& Mohammed, W. S. M. (2018). Towards an Analytical Model in Critical Pragmatics. Arab World English Journal, 9 (4), 162 -176.

Ali, A. Y. (1987). The Holy Quran: English Translation of the Meanings. Medina, Saudi Arabia: King Fahd Holy Quran Printing Complex.

Al-Tabari, Muhammed bin Jareer (270 H.). Interpretation of Al-Tabari: A Comprehensive Interpretation for the Quran. (Vol. 5 \&12). Beirut: House of Scientific Books.

Al-Marashli, Yosif Abdul-Rahman (2004). Islamic Studies: Doctrines, Religions and Old and Modern Ideological Schools. Beirut: House of Scientific Books.

Archer, D., Aijmer, K. \& Wichmann, A. (2012). Pragmatics: An Advanced Resource Book for Students. London and new York: Routledge.

Arrese, J., Haßler, G. \& Carretero, M. (2017). Introduction. In J. Arrese, G. Haßler, \& M. Carretero (Eds.), Evidentiality Revisited: Cognitive Grammar, Functional and Discoursepragmatic Perspectives (pp.1-13). Amsterdam/ Philadelphia: John Benjamins Publishing Company.

Aashur, Muhammed (1986). Racist Discrimination. Cairo: Library of Islamic Quiders.

Austin, J. L. (1962). How to do Things with Words. Oxford: Oxford University Press.

Beasley, C. (2005). Gender and Sexuality: Critical Theories, Critical Thinking. London: Sage Publications.

Bloor, M. \& Bloor, T. (2007). The Practice of Critical Discourse Analysis: An Introduction. London: Hodder Arnold.

Bohman, J. (2016). Critical Theory. In Edward N. Zalta (ed.), The Stanford Encyclopedia of Philosophy. (Fall 2016 Edition). https://plato.stanford.edu/archives/fall2016/entries/critical-theory/.

Brown, P. \& Levinson, S. (1987). Politeness: Some Universals in Language Usage. Cambridge: Cambridge University Press.

Crystal, D. (2003). A Dictionary of Linguistics and Phonetics (5 ${ }^{\text {th }}$ ed.). MA: Blackwell Publishing.

DuBois, J. (2007). The Stance Triangle. In R. Englebretson (Ed.), Stance-taking in Discourse: Subjectivity, Evaluation, Interaction (pp.139-182). Amsterdam: John Benjamins.

Essed, P. (1991). Understanding Everyday Racism: An Interdisciplinary Theory. California: Sage Publications, Inc.

Fairclough, N. (1995). Critical Discourse Analysis: The Critical Study of Language. Edinburgh: Pearson Education Limited.

Fredrickson, G. M. (2002). Racism: A Short History. Princeton: Princeton University Press. 
Geuss, R. (1981). The Idea of a Critical Theory: Habermas and The Frankfurt School. Cambridge: Cambridge University Press.

Graumann, C. \& Wintermantel, M. (1989). Discriminatory Speech Acts: A Functional Approach. In D. Bar-Tal, C. Graumann, A. Kruglanski \& W. Stroebe (Eds.), Stereotyping and Prejudice: Changing Conceptions (pp. 183- 207). New York: Springer.

Guillaumin, C. (1995). Racism, Sexism, Power and Ideology. London: Routledge University Press.

Grigga, K. \& Mandersona, L. (2015). Just a Joke: Young Australian Understandings of Racism. International Journal of Intercultural Relations, 47, 195-208. Retrieved from http://dx.doi.org/10.1016/j.ijintrel

Hart, C. (2010). Critical Discourse Analysis and Cognitive Science: New Perspectives on Immigration Discourse. New York: Palgrave Macmillan.

Hill, J. H. (2008). The Everyday Language of White Racism. MA: Wiley-Blackwell Press.

How, A. (2003). Critical Theory. New York: Palgrave Macmillan.

Ibn Katheer, Ismaeel bin Omar. (2002). Interpretation of Glorious Quran. Egypt: Revival of Egyptian Books House

Jeffries, L. (2010) Critical Stylistics. Basingstoke: Palgrave Macmillan.

Johnstone, B. (2008). Discourse Analysis. MA: Blackwell Publishing.

Korta, K. \& Perry, J. (2011). Critical Pragmatics: An Inquiry into Reference and Communication. Cambridge: Cambridge University Press.

Korta, K. \& Perry, J. (2013). Highlights of Critical Pragmatics: Reference and The Contents of the Utterance. Intercultural Pragmatics, 10(1), 161-182.

Leist, A. (2008). The Long Goodbye: On The Development of Critical Theory. Analyse and Kritik, 30, 1-24.

Leonardo. Z. \& Grubb, W. N. ( 2014). Education and Racism: A Primer on Issues and Dilemmas. New York: Routledge.

Levinson, S. (2007). Deixis. In L. Horn \& G. Ward, The Handbook of Pragmatics (97-122). MA: Blackwell Publishing.

Lyons, J. (1995). Linguistic Semantics: An Introduction. Cambridge: Cambridge University Press.

Melefa, O. M. \& Emeka, T. M. (2014). A Critical Pragmatic Analysis of the Discursive Expression of Power and Dominance in Chinua Achebe's Arrow of God. African Journal of New Writing, 52,153-174.

Mey, J. (2001). Pragmatics: An Introduction (2 ${ }^{\text {nd }}$ ed.). MA: Blackwell Publishing.

Qaraah, Abdul-Azeez Abdul-Rahman (1995). Islam, Racism and the Preference of Tribes and Coloured in Islam. Jaddah: Al-Basheer House. 
Ridha, Muhammed Rasheed (n.d.). Al-Manar Interpretation.(second impression, Vol. 6). Beirut: Al-Maarefa House.

Schjereve, R. R. (1989). The Political Language of Futurism and its Relationship to Italian Fascism. In R. Wodak (Ed.) Language, Power and Ideologies: Studies in Political Discourse (pp. 57-79). Amsterdam: John Benjamin Publishing Company.

Scruton, R. (2007). Palgrave MacMillan Dictionary of Political Thought $\left(3^{\text {rd }}\right.$ ed.) New York: Palgrave Macmillan.

Searle, J. R. (1969). Speech Acts: An Essay in the Philosophy of Language. Cambridge: Cambridge University Press.

Searle, J. (1976). A classification of Illocutionary Acts. Language in Society, 5(1), 1-23. Cambridge University Press.

Searle, J. (1979). Expression and Meaning: Studies in the Theory of Speech Acts. Cambridge: Cambridge University Press.

Skinner, Q. (2008). Is It Still Possible to Interpret Texts?. International Journal of Psychoanalysis, 89(3), 647- 654.

Tindale, C. (2009). Constrained Maneuvering: Rhetoric as a Rational Enterprise. In F. Eemeren (Ed.), Examining Argumentation in Context: Fifteen Studies on Strategic Maneuvering (pp. 41-61). Amsterdam: John Benjamin Publishing Company.

Trudgill, P. (2000). Sociolinguistics: An Introduction to Language and Society, $4^{\text {th }}$ ed. London: Penguin Group.

van Dijk, T. A. (2001). Critical Discourse Analysis. In D. Tannen; D. Schiffrin and H. Hamilton (Eds.), Handbook of Discourse Analysis (pp. 352-371). MA: Blackwell Publishing.

Van Dijk (2004). Ideology and Discourse: A Multidisciplinary Introduction. Barcelona: Pompeu Fabra University.

Van Eemeren, F. (2010). Strategic Maneuvering in Argumentative Discourse: Extending the Pragma-dialectical Theory of Argumentation. Amsterdam: John Benjamin Publishing Company.

Van Eemeren, F. \& Houtlosser, P. (2002). Strategic Maneuvering in Argumentative Discourse: Maintaining a Delicate Balance. In F. Eemeren and P. Houtlosser (Eds.), Dialectic and Rhetoric. The Warp and Woof of Argumentation Analysis (pp.131-161). Dordrecht: Kluwer.

van Eemeren, F. H. \& Houtlosser, P. (2009). Strategic Maneuvering: Examining Argumentation in Context. In F. H. van Eemeren (Ed.), Examining Argumentation in Context: Fifteen Studies on Strategic Maneuvering. (pp.1-25). Amsterdam: John Benjamins Publishing Company.

Verschueren, J. (1999a). Understanding Pragmatics, London: Arnold.

Wodak, R. (1989). Introduction. In R. Wodak (Ed.) Language, Power and Ideology (pp. xii -xx). Amsterdam/ Philadelphia: John Benjamin Publishing Company. 
Wodak, R. (2007). Pragmatics and Critical Discourse Analysis: A cross-disciplinary inquiry. Pragmatics and Cognition, 15 (1), 204-225.

Wodak, R. (2009). The Semiotics of Racism. In J. Rankema (Ed.), Discourse, of Course: An Overview of Research in Discourse Studies (pp.311- 326). Amsterdam/ Philadelphia: John Benjamin's Publishing Company.

Wodak, R. \& Benke, G. (2007). Gender as a Sociolinguistic Variable: New Perspectives on Variation Studies. In F. Coulmas (Ed.), The Handbook of Sociolinguistics (88- 105). Blackwell Publishing. Blackwell Reference Online. 